\title{
Somut Olmayan Kültürel Miras Ürünü Olarak Tören Keşkeği Geleneğinin Yöresel Sunum Farklılıkları
}

\author{
Doç. Dr. Sabri ÇELIK \\ Afyon Kocatepe Üniversitesi, Turizm Fakültesi \\ scelik@aku.edu.tr \\ https://orcid.org/0000-0001-7505-5944
}

\author{
Tolga KAYA \\ Afyon Kocatepe Üniversitesi, Turizm Fakültesi \\ tolga.kaya@usr.aku.edu.tr \\ https://orcid.org/0000-0002-8357-125X
}

\author{
Doç. Dr. Mustafa SANDIKCI \\ Afyon Kocatepe Üniversitesi, Turizm Fakültesi \\ sandikcimustafa@hotmail.com \\ https://orcid.org/0000-0002-1437-2484
}

DOI: https://doi.org/10.37847/tdtad.996704

Makale Gönderim Tarihi: 17.09.2021
Makale Türü: Araştırma Makalesi

Makale Kabul Tarihi: 29.11.2021

\section{Özet}

Amaç: Bu araştırma, Türkiye'de geleneksel tören keşkeğinin yapımı ve sunumu ile ilgili yöresel farklılıkları belirlemeyi amaçlamıştır.

Yöntem: Bu keşifsel araştırma için literatür taraması yöntemi kullanılmıştır.

Bulgular: Türkiye'de yaygın gastronomi kültürünün bir unsuru olan keşkek, her yörede farklı bir isimle anılmaktadır. Farklı yörelerde farklı sunum ritüelleri ile lapa veya jöle kıvamında hazırlanan keşkeğin hammaddesi buğdaydır.

Tartışma: Bu çalışmada, 2011 yılında UNESCO somut olmayan kültürel miras listesine dahil edilen Tören Keşkeği Geleneği ile ilgili bölgesel farklılıklar araştırma konusu olarak belirlenmiştir. Keşkek, Anadolu'da törensel sunumlarda karşılaşılan bir yemeğin genel adı olarak ifade edilmektedir. (Çekiç, 2015, s. 9). Orijinal adı "Döğme Aşı" olan sunum, halk arasında "keşkek" veya "herise" olarak anılmıştır. (Ayverdi, 2005, s. 87). Keşkek, Türkiye'nin Selçuklu döneminde ve Selçuklu öncesi İslam devletlerinde mutfağın vazgeçilmez yemeği olmuştur. Dükkan-ı Herras adlı lokantalarda satılan Keşkek, Osmanlı döneminde düğünlerde sunulan çok popüler bir kış yemeğiydi (Ayverdi, 2005, s. 87). Keşkek hazırlamak için olgun buğday taneleri alınır, biraz su eklenir ve taş havanda kabarmaya bırakılır. Yükselen buğday taneleri tahta tokmaklarla dövülür ve kırılmadan kabuklarından ayrılır. (Deniz-Yavaş, 2020, s. 684). Bayramlarda, doğumlarda, düğünlerde ve mevlitlerde keşkek yapma ritüeli bereket ve birliğin en önemli simgesidir (Deniz ve Yavaş, 2020). Sonuç olarak bu çalışma, Türkiye'de tören keşkeği geleneği ile ilgili bölgeler arası sunum farklılıklarını ortaya koymuş ve alan yazına bu bağlamda katkı sağlamıştır.

Anahtar Kelimeler: Keşkek, Tören Keşkeği Geleneği, Keşkek İsimleri, Keşkek Sunumu

\section{Local Presentation Differences of the Ceremonial Keşkek Tradition As An Intangible Cultural Heritage Product}

\section{Abstract}

Purpose: This research aimed to determine the regional differences regarding the production and presentation of traditional ceremonial keskek in Turkey.

Method: Literature review method was performed for this exploratory research. 
Findings: Keskek, as an element of the common gastronomy culture in Turkey, is known with a different name in each region. The raw material of keskek, which is prepared in the consistency of porridge or jelly in different regions, with different presentation rituals, is wheat.

Discussion: In this study, regional differences related to the Ceremonial Keskeği Tradition, which was included in the UNESCO intangible cultural heritage list in 2011, were determined as the research subject. Keskek is expressed as the general name of a dish encountered in ceremonial presentations in Anatolia. (Çekiç, 2015, p. 9). The presentation, that has an original name as "Döğme Aş1", has been commonly called "keşkek" or "herise". (Ayverdi, 2005, p. 87). Keşkek, had been an indispensable dish of the cuisine during the Seljuk period of Turkey and in the pre-Seljuk Islamic states. Keskek was sold at the restaurants called "Dükkan-1 Herras", and it was a very popular winter meal in the Ottoman period presented at weddings (Ayverdi, 2005, p. 87). To prepare keskek, ripe wheat grains are removed, some water is added and left to rise in a stone mortar. The rising wheat grains are beaten with wooden mallets are separated from their shells without breaking. (Deniz-Yavaş, 2020, p. 684). The ritual of making keskek is the most important symbol of abundance and unity for feasts, births, weddings and mawlids (Deniz and Yavaş, 2020). As a result, this study revealed the interregional presentation differences related to the ceremonial keskek tradition in Turkey and contributed to the literature in this context.

Keywords: Keşkek, Ceremonial Keşkek Tradition, Names of Keşkek, Presentation of Keşkek

\section{Giriş}

Geleneksel Anadolu mutfak kültürünün birçok uğraş sonucunda ortaya çıktığ bilinmektedir. Bu süreçte, başlangıç zamanından bu yana farklı zamanlarda gelen birçok toplumun payı büyüktür (Akın vd. 2015, s. 45). Farklı toplumların yaşadığı bir alanda yiyeceklere etnik kimlik oluşturulması zor bir olaydır. Fakat kimlik oluşturulacaksa coğrafi kimliği üzerine yoğunlaşarak yapılması gerekmektedir. Bu kapsamda keşkek de Anadolu kimliğini ortaya çıkaran geleneksel yemeklerden biridir (Uğurkan, 2019, s. 354). Orta Asya'dan gelen göçebe Türklere ait olan keşkek, günümüzde Anadolu'nun dört bir yanındaki köy düğünlerinde ikram edilmektedir (Sivrioğlu ve Dale, 2019, s. 127). Tek bir tarihi olmayan keşkek, bir çok ritüellerde ikram edilmektedir (Atasoy, 2019, s. 143). Bunlar; Hidırellez, Ramazan ve Kurban Bayramı, nevruz, adak, hayır, festival ve diğer özel günlerdir (Çekiç, 2015).Toplumsal birlik duygusunun tekrarlandığı bu tarz törenlerde keşkek, maddi varlıklardan çok somut olmayan bir kültürel varlık olarak bilinmektedir (Ilıcak ve Aydınalp, 2019, s. 180).

Keşkeğin, yemek olmasının dışında somut olmayan kültürel miras ürünü olarak değerlendirildiği bilinmektedir (Deniz ve Yavaş, 2020, s. 681). 2011 yılında UNESCO tarafından somut olmayan kültürel miras listesine alınan tören keşkeği geleneği, birlik ve beraberlik içerisinde herkesin katılımıyla gerçekleşmektedir (Teyin, 2020).

Türkiye'nin bütün bölgelerinde yapılan keşkeğin, farklı tarzlarda pişirildiği ve sunulduğu bilinmektedir. Ana malzemesi buğdaydır ve yan malzemeleri yöreden yöreye değişmektedir. Yan malzelemelerin dışında ismi, sunumu, yapılışı gibi etmenler de yöreden yöreye değişmesinde önemli bir rol oynamaktadır. Bu araştırmada keşkeğin sunumu ele alınmıştır ve bunun yanında sunumuna kadar geçen sürece de yer verilmiştir. 


\section{Literatür Taraması}

Türk mutfak kültürü, Türklerin ilk zamanlarından bugüne kadar ortaya çıkardıkları bilgi ve sosyal birikimlerinin hepsini kapsamaktadır (Çekiç, 2015, s. 4). Tarih boyunca çok çeşitli uygarlıkların birleşme ve çatışma noktasında yer alan ve günümüzde bu özelliğini korumakta olan Anadolu ve Trakya, halkın bugüne kadar taşıdığı kültür mirasını yansıtmaktadır (Özdemir, 2005, s. 19). Kültürel miras, "kişinin yaşadığı yerde oluşturduğu, biriktirdiği; geliştirerek yeni sentezlerle çoğalttı̆̆ı ve sürdürebilirliğini sağlayarak kendinden sonra gelen nesillere yansıttığı tüm bilgi, inanç ve davranışlar bütünü ile bu bütünün parçası olan nesneler" olarak bilinmektedir (Gümüşçü, 2018, s. 108).

Kültürel ve doğal mirasın korunması 2000'li yıllarda devletlerin ve toplumların ilgilendikleri konulardan biri olup, Avrupa Konseyi, Avrupa Birliği ve çeşitli organların çalışmalarının odaklandığı bir alan olarak bilinmektedir (Özdemir, 2005, s. 19).

UNESCO somut olmayan kültürel mirası, toplulukların ve bazı durumlarda bireylerin, kültürel miraslarının tamamlayıcısı olarak tanımladıkları uygulamalar, temsiller, anlatımlar, bilgiler, beceriler ve bunlara ilişkin araçlar, gereçler ve kültürel mekânlar olarak tanımlamıştır. Geçmişten geleceğe aktarılan somut olmayan kültürel miras, bireylerin ve grupların çevreleriyle, doğayla ve tarihleriyle ilişkilerine bağlı olarak sürekli bir biçimde yeniden oluşturmakta ve bu onlara kimlik ve devamlılık duygusu vermektedir (Somut olmayan kültürel mirasın korunması sözleşmesi: madde 2, 2003). Bu sözleşme kapsamında Türker ve Çelik (2012, s. 89) somut olmayan kültürel mirasları şu şekilde belirtmiştir;

- $\quad$ Somut olmayan kültürel mirasın devamında taşıyıcı işlevi gören dille birlikte sözlü gelenekler ve anlatımlar (destanlar, efsaneler, halk hikâyeleri, atasözleri, masallar, fikralar vb.),

- Görsel sanatları (karagöz, meddah, kukla, halk tiyatrosu vb.),

- $\quad$ Toplumsal uygulamalar, ritüeller ve şölenler (nişan, dügün, nevruz vb. )

- $\quad$ Doğa ve evrenle ilişkili bilgi ve uygulamalar (geleneksel yemekler, halk hekimliği, halk takvimi, halk meteorolojisi vb.),

- $\quad$ El sanatları geleneği (dokumacılık, nazar boncuğu, telkâri bakırcılık, halk mimarisi).

Kadın ve erkeklerin birlikte iş paylaşımı ve katılımlarıyla büyük kazanlarda ve açık ateşlerde, buğday ve etin birlikte pişirilmesiyle yapılan tören yemeğine keşkek, bu yemeğin etrafında gerçekleşen ritüellere de Tören Keşkeği Geleneği adı verilmektedir (www. aregem.ktb.gov.tr). Bu kapsamda Tören Keşkeği Geleneği, 2011 yılı itibari ile (Fotoğraf 1) UNESCO insanlığın somut olmayan kültürel mirasının temsili listesine alınmıştır (www.aregem.ktb.gov.tr).

Keşkek, geçmişten günümüze Anadolu' da birçok toplumsal yapının başrolünde olan törensel bir yemeğin genel adı olarak ifade edilmektedir (Çekiç, 2015, s. 9). Türkçe adı "döğme aşı"dır. Kaynaklara göre en fazla rastlanılan Farsça ismi olan "keşkek" ve Arapçası olan "herise" şeklinde isimlendirilmiştir (Ayverdi, 2005, s. 87). Türkiye Selçuklu döneminde ve Selçuklu öncesi İslam devletlerinde ise mutfağın vazgeçilmez yemeği olarak bilinmektedir. Herise ve keşkek olarak isimlendirilmiş olup pişirilip 
satıldığı yerin adı da dükkân-ı Herras'dır (Şahin, 2018: 38). Osmanlı mutfağında da keşkek çok sevilen bir kış yemeği olmakla birlikte düğünlerde de yapılmıştır (Ayverdi, 2005, s. 87). Günümüzde ise yapımı çok uzun sürüdüğünden dolayı düğünlerde ve özel günlerde eskiye oranla daha az tercih edilmektedir (Çınar, 2019, s. 85)

Keşkeğin ana maddesi durumundaki keşkeklik buğday için olgunlaşmış buğday taneleri ayıklanır, biraz su eklenir ve taş dibek içerisinde kabartılmaya bırakılır. Kabaran buğday taneleri belirli bir ritimle ahşap tokmaklar ile dövülerek buğday tanelerini kırmadan kabuklarından ayrılması sağlanmaktadır (Deniz-Yavaş, 2020, s. 684). Keşkeğin yapımı etnik, kültürel ve dinsel özelliklere göre değişim sağlasa da keşkek ve keşkek yapım ritüeli bayram sabahlarında, doğumda, sünnet düğünlerinde, bayramlarda ve mevlitlerde bereketin ve birlikteliğin en önemli sembolü durumundadır (Deniz ve Yavaş, 2020). Türkiye'de yapılan geleneksel keşkek, belirli törenlerde gerçekleştirilen ritüellerde herkesin katılımıyla birlik ve beraberlik içerisinde gerçekleşmektedir (Teyin, 2020, s. 313).

Keşkek, "karmaşık" olarak ifade edilen bir yemektir. Karmaşık olmasının sebebi ise geniş bir coğrafyaya yayılmış olması ve bunun yanı sıra hazırlanış şeklinin, içerisine ilave edilen yiyecek maddelerinin ve keşkekle kastedilen yiyecek türlerinin de bölgeden bölgeye önemli farklılıklar göstermesidir (Sarı, 2011, s. 54).

Geleneksel Türk Mutfağının en önemli lezzetlerinden olan keşkeğin Türkiye'de her bölgede ve her yörede yapıldığı bilinmektedir (Teyin, 2020, s. 313). Yöresel olarak diğer yemekler gibi farklı bölgelere gidildikçe yemeklerin yapımında ve reçetesinde ufak değişiklikler bulunmaktadır (Şahin, 2018, s. 206) Genellikle Ege, Akdeniz ve İç Anadolu olmak üzere Türkiye'nin her bölgesinde yapılmakta olan keşkeğin, yöreden yöreye isminde değişiklik olduğu görülmektedir. Dövme pilavı/ dövme aşı (Hatay, Adana Gaziantep), herse (Rize), herise (Konya, Gaziantep), hırisi- hirisi (Hatay), gendirme pilavı (Erzincan), aşür, etli aşure (Hatay) bunlardan birkaçıdır (Çekiç, 2015).

Sarışık ve Özbay (2019), Akdeniz Bölgesi'nde bulunan; Hatay, Adana, Antalya, Doğu Anadolu Bölgesinde bulunan; Ağrı, Ardahan, Bingöl, Iğdır, Muş, Ege Bölgesinde bulunan; Denizli, İzmir, Kütahya, Muğla, Uşak, Güneydoğu Anadolu Bölgesinde bulunan; Şırnak, İç Anadolu Bölgesinde bulunan; Ankara, Çankarı, Karaman, Kırşehir, Karadeniz Bölgesinde bulunan, Amasya, Artvin, Bartın, Bolu, Gümüşhane, Karabük, Samsun, Sinop, Tokat, Marmara Bölgesinde bulunan; Balıkesir, Bursa, Çanakkale, Kocaeli, Sakarya illerinde keşkek yapıldığını ve tüketildiğini belirtmektedir.

\section{Akdeniz Bölgesi}

Adana: Düğünlerde, kırk yemeklerinde (Arslantaş, 2020) ve Kurban Bayramlarında genellikle bulgur pilavı ya da buğdaydan yapılan etli bir yemek olan hrisi (herise/ heresi) yer almaktadır. Genel olarak kazanlarda yapılmaktadır (Keser, 2005).

Antalya: Antalya merkez ve ilçe köylerde, düğünlerde, mevlitlerde, özel gün yemeklerinin vazgeçilmezidir. Ana maddesi buğdaydır ve dibekte ezilmeden dövülen buğdaylar, rüzgarda kabuklarından arındırılır. Bol su ile hafif ateşte pişer ve özleşince ateşten alınır. Sıcak olarak servis edilerek üzerine, kavrulmuş kırımızı toz biberle eritilmiş tereyağı gezdirilerek et yemeklerinin yanında servis edilir (Çimrin, 2006). 
Hatay: Bölgede kutsallık kazanan keşkek bayram ve adakların başyemeği olarak bilinmektedir ve yapan kişinin erkek olması, ahlaki ve dini açıdan iyi izlenim bırakan kişi olmasıyla birlikte hrisi yapılacak mutfak eşyalarının dua okunarak yıkanması gerekmektedir (Türk-Şahin, 2004). Bir diğer ismi aşürdür ve kimyon ve tereyağ1 eklenerek aşürün üzerine dökülür (Çekiç, 2015, s. 57).

Isparta: Yalvaç'ın geleneksel lezzetleri arasında olan keşkek, fırının içerisinde yanan gazallerin küllerinde pişirilmektedir. Çömlekte yapılır ve yenmeden bir gün önce çömlek fırına verilir (Göde, 2017, s. 201).

\section{Ege Bölgesi}

Afyonkarahisar: Sönmüş taş fırınlarda sabaha kadar hevik ismi verilen büyük güveç kaplarda pişirilmektedir. İçerisine büyük baş hayvanların ilikli eklem kemikleri ve pöç eti ilave edilir. Sunumu gerçekleşmeden önce içerisine Afyonkarahisar'ın manda kaymağı eklenerek kıvamı oluşana kadar dövülür (Çelik, 2019, s. 45). Bu keşkeğe Şuhut keşkeği denilmektedir ve coğrafi işarete sahiptir. Bazı ilçelerinde dövülmeden de sunulduğu görülmektedir. Çoğunlukla Kurban bayramı sabahlarında aileleri bir araya getirmektedir.

Denizli: Elit kesimde kuzu etinden yapılmaktadır (Çınar, 2019, s. 75). Babadağ keşkeği, Babadağ ilçesinde tüketilmektedir. Keşkek, yağlı keçi veya koç eti, dövülmüş buğdaydan yapılmaktadır. Genel olarak düğünlerde yapılır ve iki ayrı kazanda et ve buğday pişer, buğdayın suyu azaldıkça etin suyundan ilave edilir. Pişen et kemiklerinden ayrılarak dövülür ve buğdayın içerisine ilave edilir. Sıcak olarak kırmızı biberli tereyağı ilave edilir. Turşu ve salata ile servisi sağlanır (URL-1, 2021). Denizli'nin Çivril ilçesinde Çivril keşkeği olarak adlandırılan keşkeğin sunumu: salça soslu etin, keşkeğin üzerine koyularak yapılmaktadır (URL-2, 2021).

İzmir: İzmir'de her bölgede düğünlerde yapılan keşkek, vazgeçilmez bir yemektir (URL-3, 2021). Geçmişte keşkeği kuzu etinden yaptıkları bilinmektedir (Çınar, 2019: 52). Temel olarak buğday ve etten (kırmızı veya beyaz et) hazırlanmakta ve düğün günü aynı kazanda kaynatılmaktadır. Pişme işleminden sonra tokmak ile iyice erimesi sağlanır ve pelte kıvamına getirilmektedir. Yöreye göre kırmızıbiber, salça, tereyağından sos yapilmaktadır (URL-4, 2021).

Muğla: Nevruz etkinliklerinde (Çekiç, 2015, s. 26), dügünlerde muhakkak keşkek olur ve bu keşkek etsiz ve bol tereyağlı olur. Büyük bakır kazanlarda odun ateşinde ağır ağır karıştırılarak pişirilmektedir (Çınar, 2019, s. 55).

Aydın: Genel olarak düğünlerde sunulmaktadır. Ayrı yerlerde kaynatılan et ve buğdaylar daha sonrasında tek bir kazanda birleştirilip tahta kepçe ile dövülerek sakız kıvamına getirilmektedir. Servis esnasında kırmızıbiberli terayağı ilave edilir (Aydın, 2000, s. 47). Aydın'ın Karacasu ilçesinde cografi işaret alan dedebağ keşkeği hayır olarak dağıtılmaktadır. Yedi asırdır devam eden gelenekte keçi eti kullanılarak ve odun ateşinde bakır kazanlarda dövülerek yapılmaktadır. Macun kıvamında olan bu keşkek tadında is kokusu bulunmaktadır (URL-5, 2021). 
Kütahya: Düğünlerde servis edilen etler, keşkekle karıştırılmadan ayrı ayrı kazanlarda pişirilmektedir. Pişen et keşkeğin üzerine ilave edilerek etin yağ gezdirilerek servis edilmektedir (URL-6, 2021).

Uşak: Düğün, sünnet ve mevlitlerde kazanda pişirilen keşkek sunum aşamasındaki sıradan dolayı pilav ile beraber ikram edilmektedir (Togay, 2016, s. 63). Evlerde çömlekte yapılan keşkek, sosunda bulunan domates, salça, kuşbaşı et ile ikram edilmektedir (Altınten, 2021).

Manisa: Kula ilçesinde pişirilen keşkekler düğünlerde ikram edilmektedir ve evde yapılan keşkek yemeğini çömlekte pişirmektedirler (Bozkurt ve Özkoca, 2012, s. 668).

\section{İç Anadolu Bölgesi}

Çankırı: Buğday belirli bir süre dibekte dövüldükten sonra, tereyağı ile kavrulan etin üzerine su, buğday, tuz konularak fırına verilerek pişirilir (URL-7, 2021). Aynı zamanda düğün yemeklerinin vazgeçilmezidir (Şentürk, 2019).

Kırşehir: Keşgâh olarak isimlendirilmektedir. (Yurday ve Kıngır, 2019, s. 410). Dövülmüş buğday ile lif haline getirilmiş yağlı et muhallebi kıvamına gelinceye kadar pişirilir. Yapıldıktan sonra üzerine salçalı yağ ilavesi yapılarak servis edilir (URL-8, 2021).

Aksaray: Herse olarak bilinmektedir. Büyükbaş veya küçükbaş hayvanın yağlı kaburga etinden yapılmaktadır. Tandır içerisine çömlek indirilerek yapılır. Kışın yapılan hersenin eti kuru et olarak kullanılır. Düğün yemeği olarak tüketilmez, normal öğündür (URL-9, 2021).

Sivas: Sivas yöresinde ise: bulgur, yoğurt, su ve tereyağ1 ile yaplır. Yoğurdun içerisinde haşlanan bulgur servis edilme esnasında ortası açılarak eritilmiş tereyağ dökülür (URL-10, 2021).

\section{Doğu Anadolu Bölgesi}

Ağrı: Herise, halise, keşkek, aşur ve daha bir çok adı vardır. Ağrı yöresindeki genel ismi halisedir. Buğday ve kuzu eti bakır kazanda geceden fırına koyularak, sabah fırından çıkarıldıktan sonra kazan içerisindeki malzemeler ahşap tokmakla dövülmektedir. Üzerine ise yakılmış sarı yağ ilave edilmektedir (Akkor, 2016, s. 160).

Tunceli: Bu yörede keşkek geleneksel bir rol oynar. Ayran içerine ilave edilen bulgurların pişirilmesinden sonra un katılarak hamur haline getirilen keşkek, ortasına tereyağ eritilerek servis edilir (Gültekin, 2007, s. 106).

Elazığ: Masuta olarak bilinen keşkek; ayran, bulgur ve yumurta ile yapıldığ bilinmektedir. En son servis esnasında ortasına tereyağı dökülmektedir. Genel olarak evlerde yenilmektedir (URL-11, 2021).

Erzincan: Erzincan'da bulunan Kemaliye ilçesinde, Kemaliye keşgeyi yapılamaktadır. Kuzu etinden, kazanlarda yapılan keşkek macun halinde servis edilir. Ana yemek veya düğünlerde tüketilmektedir (Yücel vd. 2013, s. 41). Genel anlamda keşkeğe, aşür, etli aşür ve etli aşure ismini kullanmaktadırlar (Çekiç, 2015, s. 10). 
Erzurum: Hınıs ilçesinde bulunan hınıs keşkeği yöreye özgü bir yiyecektir. Kemikli et, dövme ve nohut ana malzemesidir. Kaynatılıp hazırlanan keşkeğin ortası açlarak yağ dökülür ve servis edilir (URL-12, 2021).

Kars ve Iğdır,: Bu yörelerde keşkek yapımına çok benzeyen "haşıl" tüketilmektedir. Bu haşıl kars yöresinde: Buğday, un, tuz, yoğurt, sarımsak, tereyağı ile yapılmaktadır. Haşlanan sulu buğday un ile bağlanır daha sonra sarımsaklı yoğurt ve eritilmiş tereyağ ile servis yapılır. Iğdır yöresinde de haşıl tüketildiği bilinmektedir (Saatci, 2019, s. 373).

Malatya: Çideme olarak adlandırılan keşkek, kaynatılan ve suyunu çeken döğmeye yağda yakılan toz biber ve salça döklülerek biraz daha pişirilir ve servis edilir (URL-13, 2021).

Muş: Bölgede, keşkek sofrasında sözlü kültür ürünü olan tekerleme söylenmektedir. "keşkeklenmiş keşkekçinin keşkek kepçesi" şeklinde olan tekerlemeyi, söyleyemeyen kişi ziyafet vermektedir (Çekiç, 2015, s. 50). Herse olarak adlandırılmaktadır. Kemiklerden ayrılmış et haşlanır, ayrı bir yerde den (suda haşlanarak hazırlanmış buğday) suda kaynatılır. Eti kaynayan denin üzerine dökülür. Sonra etle den iyice karıştırılır. Daha sonra bolca yağ dökülerek sahanlarda sevis edilir (URL-14, 2021).

Van: Den, nohut ve et kullanılarak yapılmaktadır, Muş yöresine benzeyen keşkek lapa kıvamında salça veya pılbiber ile kızdırılmış yağ ile servis edilmektedir (URL-15, 2021).

\section{Güneydoğu Anadolu Bölgesi}

Kilis: Keşkeği genel olarak kıyma ile yapmaktadırlar. Bu yüzden keşkeğe "kel keşkek" ismini vermişlerdir. Kilisin gündelik yemekleri arasında önemli bir yer tutmaktadır (Çekiç, 2015, s. 54). Ramazan ayının ilk günü hazırlanmaktadır. Ramazan ayı boyunca, yemeği yapan kişinin vefat eden yakınları için keşkeğin içerisindeki döğme taneleri kadar tesbih çektiği bilinmektedir (Alptekin, 2021, s. 166).

Gaziantep: Herise olarak bilinen keşkek (Çekiç, 2015: 10), döğme ile etin pişirilmesi ile elde edilir. Yörede "yağlı etten olur herise, erkek kazanıp getirsin er ise" sözü ile helisenin yağlı etten yapıldığı anlaşılmaktadır (URL-16, 2021).

Diyarbakır: Herse olarak adlandırılmaktadır (Karakaş ve Alkış, 2015, s. 7). Et veya kavurma, dövme, nohut, domates, biber ve pul biber bulunmaktadır. Rengi kırmızı ve kıvamı lapa şeklindedir (URL-17, 2021).

Siirt: Hıntiyye olarak isimlendirilmektedir (Çildam, 2021, s. 312). Kemikli et, dövme ve nohut kullanılarak yapılmaktadır (URL-18, 2021). İsteğe göre kuşbaşı eti eklenmekte ve dometes ilave edilmektedir. Rengi kırmızı ve lapa kıvamındadır (URL-19, 2021).

Mardin: Kuzu eti, buğday ve nohut ile yapılmaktadır. Sadeyağ kullanımı mevcuttur aynı zamanda kemikleri ile servis edilir. Daha heterojen bir yapıya sahiptir (URL-20, 2021). 


\section{Karadeniz Bölgesi}

Artvin: Dibekte dövülerek hazırlanan yemek, halk arasında "gendime" ve "keşkek" olarak bilinmektedir (URL-21, 2021). Et, buğday ve nohut ile yapılmakta ve etin suyu ile nohut ve buğday pişirilmektedir (URL-22, 2021).

Rize: Keşkek, herse olarak isimlendirilmektedir (Çekiç, 2015, s. 10).

Bayburt: Herse olarak isimlendirilen keşkek, buğday, tavuk ve tereyağı ile yapılmaktadır. Lapa ve açık bir renge sahiptir (URL-23, 2021).

Gümüşhane: Gendüme pilavı olarak bilinmektedir (URL-24, 2021). Yarma (gendime), kıyma, fasulye ile yapilmaktadır (URL-25, 2021).

Giresun: Bölgede keşkek festivalleri oldukça fazladır (Çekiç, 2015, s. 75). Aynı zamanda Ramazan ve Kurban Bayramı, düğün ve nişanda keşkek bulunmaktadır. Gendime (buğday) ve et ile hazırlanır ve lapa kıvamındadır (Demirel ve Ayyıldız, 2017).

Ordu: Gendeme (Buğday) olarak bilinir. Ramazan ve Kurban Bayramında ve düğ̈ünlerde yapıldığı bilinmektedir (URL-26, 2021).

Tokat: Keşkeğin yapımında kadınlara büyük sorumluluk düşmektedir. Fazla dövülmeyen keşkek, kadınlar tarafından kontrol edilmektedir (Çekiç, 2015, s. 36). Tokat' da içerisine bazen çemen ve pastırma eklendiği bilinmektedir (Mertol ve Yaylacı, 2021, s. 319). Nohut, et, yarma ve tereyağı ile fırında yapılmaktadır. Dügüunlerde servis edilir (URL-27, 2021).

Amasya: Keşkek, düğün evlerinde buğday, koyun eti, koyun kuyruğu, nohut ve çemen kullanılarak yapılmaktadır. Merzifon yöresinde bir cabın (çömlek) içerisinde dövülerek macun haline getirilir (Yörgüç, 2010). Bu kapsamda Amasya'nın Merzifon keşkeği imgesel bir yemek olarak karşımıza çıkmaktadır (Çekiç, 2015, s. 55).

Samsun: Genellikle mevlitlerde yapılan keşkek tahta kepçeler ile dövülerek yapılmaktadır. Samsun'un Bafra ilçesinde yapılan keşkek; buğday, tavuk ve tereyağı ile yapılarak toz biber ilave edilmektedir. Lapa kıvamlı ve açık renktedir (URL-28, 2021).

Sinop: Sinop'a bağlı Ayancık ilçesinde yapılan keşkekte et kullanılmaz fakat barbunya ve mısır eklenmektedir. Mısır keşkeği olarak adlandırılmaktadır (Çekiç, 2015, s. 53). Özellikle düğün yemeği olarak yapılır (Genç ve Seçim, 2019).

Çorum: Bir gelenek olarak yapılan keşkeğin Çorum'da ana malzemesi buğday ve ettir. Fakat soğan ve kuyruk yağı kullanımı yaygındır. Bakır kazanda ve ağaç kaşıkla sürekli ezilerek yapılır. Aynı zamanda üzerine yahni koyularak ikram edilebilir. (Atasoy, 2019). Çorum iline bağlı İskilip ilçesinde yapılan iskilip keşkeği, çömleklerde pişirilmektedir ve üzerinde kabuk vardır (URL-29, 2021).

Kastamonu: Keşkek çorbası olarak bilinen yöresel yiyeceğin yörede tüketildiği bilinmektedir (Akkuş ve Şimşek, 2019, s. 48). Aynı zamanda etli keşkek tüketimi vardır (Akkuş vd. 2019, s. 428). 
Bartın: Keşkek pilavı olarak isimlendirilmektedir. Genel olarak bayramlarda ve düğünlerde ikram edilir. Buğday, soğan, tereyağı kullanılır pilav görümünde olup rengi kirmizidır (URL-30, 2021).

Karabük: Halk arasında taş fırın veya kara fırın keşkeği olarak adlandırılan keşkek çömleklerde fırında pişirilir. Sığır veya ineğin gerdanı kullanılarak hazırlanmaktadur. Bayram sabahlarında, doğumda, düğünlerde, muharrem ayında bereketin ve sembolün konumundadır (Deniz ve Yavaş, , 2020, s. 684). Aynı zamanda yörede sütlü keşkek çorbasıda tüketilmektedir. Süt içerisinde kaynatılan keşkek tereyağı ve salça ile servis edilir. Suludur ve beyazdir (URL-31, 2021).

Zonguldak: Islanan buğday, yulaf, nohut, barbunya, fasulye ve kırmızı et kazana koyulup kaynatılır. Kıvamını koyulaştırması için nişasta eklenir ve daha sonra tahta tokmak ile macun haline getirilerek üzerine yağ gezdirilir (URL-32, 2021).

Bolu: Aşurelik buğday ile dana eti veya koyun eti pişirilir, iyice pişmiş et alınıp didiklendikten sonra tekrar keşkek ile dövülür. Üzerine tereyağı ile kavrulup kıyılmış soğan eklendiği bilinmektedir (URL-33, 2021).

Gök (2019), yaptığı çalışmada Gümüşhane bölgesinde halkın ağı incelemesini gerçekleştirmiştir. Köylülerin "gendime pilavı" olarak aktardığı gendime kelimesi, kendime anlamını taşımaktadır.

\section{Marmara Bölgesi}

Edirne: Trakya usülü keşkek olarak adlandırılan keşkek, buğday, tereyağı, tavuk göğsü, süt ve kırmızı biber ile yapılmaktadır. Dügün, mevlütlerde hazırlanmaktadır (URL-34, 2021).

Tekirdağ: Herise olarak bilinen keşkek, kuzu eti, buğday ve tereyağından yapılmaktadır. Dügüülerde tüketilir (URL-35, 2021). Aynı zamanda ilçede keşkek şenliği yapılmaktadır (Topcuoğlu ve Kiper, 2020, s. 517).

Çanakkale: Keşkek, koyun eti ve kabuğu alınmış buğday ile birlikte pişirilerek elde edilmektedir. Aynı zamanda içerisinde yağ ve nohut vardır. Toplu ikramlarda servis edilmektedir (Erol, 2004).

Kocaeli: Köy tavuğu, buğday, kuru fasulye, tereyağı ile yapılan keşkek, muhallebi kıvamına gelince salça veya pulbiber ile servis edilmektedir. İzmit yöresinde ise dartı kullanımı vardır (URL-36, 2021).

Sakarya: Genel olarak kına gecelerinde ikram edilen keşkek, “Adapazarı Dartılı Keşkek" olarak isimlendirilmektedir (Uğurkan, 2019, s. 357). 2009 yılında çoğrafi işaret alan dartılı keşkek, süt, tavuk, buğday ana malzemleri ile hazırlamaktadır (Türk Patent ve Marka Kurumu, 2012). Sütün yağını çıkararak elde edilen dartının Adapazarı'nda keşkekte kullanılması, diğer keşkeklerden ayırmıştır (Ŭ̆urkan, 2019).

Bilecik: Düğünden bir gün önce köy halkı keşkek dövmektedir. (Vurgun, 2018, s. 497). Buna göre yöre halkı düğünlerde keşkek yapmaktadır. 
Bursa: Klasik keşkeğin reçetisi ile hazırlanmaktadır fakat içersine mısır ilave edilmektedir. Bu yüzden halk arasında mısırlı keşkek olarak bilinmektedir (Çekiç, 2015, s. 53).

Balıkesir: Keşkek, kuzu kemiği, buğday, salça ve tereyağı ile yapılmaktadır. Et belli olmayana kadar dövülür (URL-37, 2021). Merhem kıvamında olan keşkek, düğünlerde sunulmaktadır (Demirel ve Karakuş, 2019, s. 1391).

\section{Araştırmanın Amacı ve Yöntemi}

Araştırmanın amac1, somut olmayan kültürel miras ürünü olan tören keşkeği geleneği sunumunun yörelere göre farklılıklarının ortaya koymaktadır. Araştırmanın alt amacı ise bölgelerde farklı isimler ile bilinen keşkek türlerini belirlemektedir. $\mathrm{Bu}$ kapsamda, her yörede farklı ritüellere, isim ve yapılış şekline sahip olan keşkek, genelden özele gidilerek araştırılmıştır.

Çalışma, nitel araştırma yöntemi olan kaynak tarama yöntemi ile gerçekleştirilmiş keşifsel bir araştırmadır. Keşkek ile ilgili fazla kaynak olmadığından internet siteleri de araştırmaya dâhil edilmiştir. Bu kapsamda bu çalışmanın keşkek ile ilgili diğer çalışmalara kaynak olacağı düşünülmüştür.

Araştırma kapsamına, Türkiye'de bulunan ve yapım, sunum ve isimlerinde farklılık olan keşkekler dâhil edilmiştir. Dâhil edilmeyen keşkeklerin herhangi bir farklılığ 1 olmadığ 1 için çalışma dişında tutulmuştur.

\section{Bulgular}

Türkiye' de keşkeklerin Tablo 1'de görüldügü gibi halk arasında farklı farklı isimlerle adlandırıldığı bilinmektedir. Yiyecekler en çok keşkek ismi ile anılmaktadır. Aynı zamanda yapılışlarına ve görünüşlerine göre farklı isimlendirilmektedir ancak pek çok şehirde herse olarak adlandırıldığı, Kastamonu' da da keşkek çorbası olarak yapıldığı da görülmektedir.

Tablo 1: Keşkeklerin şehirlerdeki ismi

\begin{tabular}{|l|l|l|l|}
\hline Yapıldı̆̆ı şehir & Yöredeki ismi & Yapıldığı şehir & Yöredeki ismi \\
\hline Adana & Hrisi & Gaziantep & Herise \\
\hline Hatay & Hrisi- Aşür & Siirt & Hıntiyye \\
\hline Afyonkarahisar & Keşkek-Şuhut keşkeği & Giresun & Gendime \\
\hline Denizli & Babadağ keşkeği & Artvin & Gendime \\
\hline Aydın & Dedebağ keşkeği & Rize & Herse \\
\hline Kırşehir & Keşgâh & Bayburt & Herse \\
\hline Aksaray & Herse & Gümüşhane & Gendime pilavı \\
\hline Sivas & Haşı & Amasya & Merzifon keşkeği \\
\hline Ağrı & Halise & Sinop & Mısır keşkeği \\
\hline Elazı̆̆ & Masuta & Çorum & İkilip keşkeği \\
\hline Erzincan & Aşür, etli aşür, etli aşure & Kastamonu & Keşkek çorbası \\
\hline Erzurum & Hınış keşkeği & Bartın & Keşkek pilavı \\
\hline Malatya & Çideme & Karabük & Kara fırın / \\
\hline Diyarbakı̈ır & Herse & & Sütlü keşkek \\
\hline
\end{tabular}




\begin{tabular}{|l|l|l|l|}
\hline Muş & Herse & Tekirdağ & Herise \\
\hline Kars & Haşıl & Sakarya & Dartılı keşkek \\
\hline Kilis & Kel keşkek & Bursa & Mısırlı keşkek \\
\hline
\end{tabular}

Tablo 2'de görüldüğü gibi keşkek yapımında buğday kullanımı olukça fazladır. Bunun yanında içerisindeki diğer malzemeler yöreye göre değişiklik göstermektedir. Pişirme alanı ve pişirme aracı belirtilmeyen keşkeklerin net bir pişirme tarzı olmadığ 1 bilinmektedir.

Tablo 2: Keşkek malzemesi ve pişirilme farklılıkları

\begin{tabular}{|c|c|c|c|}
\hline Yapıldığı şehir & Ana malzemeler & \begin{tabular}{|l} 
Pişirme \\
alanı
\end{tabular} & Pişirme aracı \\
\hline Adana & Buğday veya bulgur, et & Ateş & Kazan \\
\hline Isparta & Buğday, et, & Firin & Çömlek \\
\hline Afyonkarahisar & Buğday, pöç eti, kaymak & Firın & Güveç \\
\hline Denizli & Buğday, yağlı keçi veya koç eti & Ateş & Kazan \\
\hline Muğla & Buğday ve tereyağ 1 & Ateş & Bakır kazan \\
\hline Aydın & Buğday, keçi eti & Ateş & Bakır kazan \\
\hline Kütahya & Buğday, et & Ateş & Kazan \\
\hline Uşak & Buğday, et, domates, salça & Firın & Çömlek \\
\hline Çankırı & Buğday, et & Firın & Çömlek \\
\hline Aksaray & Buğday, yağll kaburga, & Tandır & Çömlek \\
\hline Ăgrn & Buğday, kuzu eti, sarı yağ & Firın & Bakır kazan \\
\hline Erzincan & Buğday, kuzu eti, & Ateş & Kazan \\
\hline Tokat & Buğday, çemen veya pastırma, nohut & Firin & Çömlek \\
\hline Amasya & Buğday, koyun eti ve kuyruğu, & Firın & Çömlek \\
\hline Karabük & Sığır gerdanı, süt, tereyağı, salça & Firın & Güveç \\
\hline Zonguldak & Buğday, et, yulaf, nohut, barbunya, fasulye & Ateş & Kazan \\
\hline Çorum & Buğday, et, soğan, kuyruk yağ 1 & Ateş & Bakır kazan \\
\hline Sivas & Bulgur, yoğurt, tereyağ 1 & & \\
\hline Tunceli & Bulgur, ayran, un, tereyağı & & \\
\hline Elazı $\breve{g}$ & Bulgur, ayran, yumurta & & \\
\hline Erzurum & Buğday, kemikli et, nohut & & \\
\hline Iğdır & Buğday, un, yoğurt, sarımsak & & \\
\hline Malatya & Buğday, toz biber, salça & & \\
\hline Van & Buğday, et, nohut, salça & & \\
\hline Kars & Buğday, beyaz un, yoğurt, sarımsak & & \\
\hline Kilis & Buğday, kıyma & & \\
\hline Diyarbakir & Buğday, et, kavurma, nohut, domates biber & & \\
\hline Siirt & Buğday, Kemikli et, nohut & & \\
\hline Hatay & Buğday, Et, kimyon & & \\
\hline Mardin & Buğday, kuzu eti, nohut & & \\
\hline Artvin & Buğday, dana eti, nohut & & \\
\hline Bayburt & Buğday, tavuk, nohut & & \\
\hline Gümüşhane & Buğday, kıyma, fasulye & & \\
\hline Giresun & Buğday et, & & \\
\hline Samsun & Buğday, tavuk, tereyağ & & \\
\hline
\end{tabular}




\begin{tabular}{|l|l|}
\hline Sinop & Buğday, mısır, barbunya \\
\hline Bartın & Buğday, soğan, tereyağı \\
\hline Bolu & Buğday, et, tereyağı, soğan \\
\hline Edirne & Buğday, tavuk, süt, tereyağ 1 \\
\hline Tekirdă̆ & Buğday, kuzu eti, tereyağı \\
\hline Çanakkale & Buğday, koyun eti, nohut \\
\hline Kocaeli & Buğday, köy tavuğu, tereyağ 1 \\
\hline Sakarya & Buğday, tavuk, süt \\
\hline Bursa & Buğday, mısır \\
\hline Balıkesir & Buğday, salça \\
\hline
\end{tabular}

İçerisinde bulunan malzemelere göre renk değiştiren keşkekler tablo 3' de açık gri, gri, beyaz, kırmızı ve koyu olarak belirtilmiştir. Farklı kıvamlarda sunumu yapılan keşkeklerin macun, sakız, pelte, lapa, muhallebi ve macun kıvamında olduğu anlaşılmıştır. Bir diğer değerlendirme kriteri ise sunum şeklidir. Keşkeklerin sunumunda üzerine dökülen veya konulan ürünler yine aynı tablo üzerinden belirtilmiştir.

Tablo 3: Keşkeklerin kıvamları, renkleri ve sunum şekilleri

\begin{tabular}{|c|c|c|c|}
\hline Yapıldığı şehir & Kivam & Renk & Sunum şekli (üzerine) \\
\hline Antalya & Macun & Açık gri & Kırmızı yağ \\
\hline Hatay & Macun & Gri & Tereyağında kavrulmuş kimyon \\
\hline Afyonkarahisar & Macun & Gri & Kırmızı yă̆ \\
\hline İzmir & Pelte & Açık gri & Kırmızı tozbiber ve salçalı tereyağı \\
\hline Denizli & Macun & Gri & Kırmızı yağ ve yanında turşu, salata \\
\hline Aydın & Sak1z & Açık gri & Kırmızı yağ \\
\hline Kütahya & Pelte & Açık gri & Et ve etin yağ1 \\
\hline Uşak & Macun & Açlk gri & Yanında pilav \\
\hline Kırşehir & Muhallebi & Gri & Yakılmış sarı yağ \\
\hline Ăgr1 & Macun & Gri & Salçalı yağ \\
\hline Tunceli & Pelte & Açık gri & Ortasına eritilmiş tereyağı \\
\hline Elazı̆̆ & Pelte & Açık gri & Ortasına eritilmiş tereyağ 1 \\
\hline Erzurum & Lapa & Açık gri & Ortasına eritilmiş tereyağ \\
\hline Erzincan & Macun & Gri & Kırmızı yağ \\
\hline Kars & Lapa & Açık gri & Sarımsaklı yoğurt ve eritilmiş tereyağ 1 \\
\hline Sivas & Lapa & Açık gri & Ortasına eritilmiş tereyağ \\
\hline Muş & Muhallebi & Gri & Sahanda \\
\hline Van & Lapa & Gri & Salça veya kırmızıbiber ile kızdırılmış tereyağı \\
\hline Diyarbakır & Lapa & Kırmız1 & Eritilmiş tereyağ1 \\
\hline Siirt & Lapa & Kırmız1 & Eritilmiş tereyağ1 \\
\hline Mardin & Lapa & Gri & Üzerine kemikli et \\
\hline Bayburt & Lapa & Açık gri & Eritilmiş tereyağ1 \\
\hline Samsun & Lapa & Açık gri & Tereyağlı kırmızıbiber \\
\hline Çorum & Sakiz & Koyu & Üzerine yahni \\
\hline Bartın & Lapa & Kirm1z1 & Eritilmiş Tereyağ1 \\
\hline Karabük & Sulu & Beyaz & Eritilmiş tereyağlı salça \\
\hline Zonguldak & Macun & Beyaz & Eritilmiş tereyağ 1 \\
\hline
\end{tabular}




\begin{tabular}{|l|l|l|l|}
\hline Bolu & Macun & Koyu & Tereyağında kavrulmuş soğan \\
\hline Kocaeli & Muhallebi & Açı gri & Eritilmiş tereyağlı salça \\
\hline Balıkesir & Merhem & Açı gri & Eritilmiş tereyağlı salça \\
\hline
\end{tabular}

Törensel bir yemek olduğu bilinen keşkeğin şehirlerde hangi ritüeller bazında gerçekleştirildiği tablo 4'de belirtilmiştir. Bu kapsamda benzer özeliği taşıyan şehirler aynı sütun içerisinde yer almıştır. Genel olarak düğün, Ramazan ve Kurban Bayramları, mevlit ve nişanlarda servis yapıldığı bilinmektedir.

Tablo 4: Keşkeğin şehirlerde sunulduğu ritüeller

\begin{tabular}{|l|l|}
\hline Gerçekleşen Ritüeller & Şehirler \\
\hline Düğün & $\begin{array}{l}\text { Denizli, Aydın, İzmir, Kütahya, } \\
\text { Manisa, Çankırı, Aksaray, Erzincan, } \\
\text { Tokat, Amasya, Sinop, Bilecik, } \\
\text { Balıkesir }\end{array}$ \\
\hline Düğün, kırk yemekleri ve kurban bayramı & Adana \\
\hline Düğün, mevlit ve özel günler & Antalya, Uşak \\
\hline Bayramlar ve adaklar & Hatay \\
\hline Düğün ve nevruz & Muğla \\
\hline Özel günler & Muş \\
\hline Ramazan Bayramı & Kilis \\
\hline Ramazan ve Kurban bayramı, düğün, nişan & Giresun, Ordu, Bartın \\
\hline Mevlit & Samsun \\
\hline Bayram sabahları, doğum, düğün, Muharrem ayı & Karabük \\
\hline Düğün ve mevlit & Edirne \\
\hline Kurban Bayramı sabahı & Afyonkarahisar \\
\hline
\end{tabular}

\section{Sonuç}

Türkiye'de keşkeğin bütün bölgelerde yapıldığı bilinmektedir fakat araştırma dahilinde olan keşkekler yapımında ve sunumunda farklılık olan keşkek türleridir. Bu kapsamda da 56 tane şehirde isim, sunum ve malzeme bakımından farklı olan keşkekler incelenmiştir. Birbirlerine yakın olan bölgeler benzer özellikler taşımaktadır. Bu benzerlik; isim, malzeme, pişirme şekli ve sunumudur.

Türkiye'de bulunan şehirlerin bazıları, yiyeceklerde ve yemeklerinde farklı isimler kullanmaktadır. Keşkek kelimesi de bu farklılıklardan birisidir. Bazı bölgelerin ve şehirlerin, konumu ve yapım şekine göre isimlendirildiği keşkek çeşitleri vardır. Buna göre toplam 28 farklı keşkek ismine ulaşılmıştır. Bunlar; Hrisi, Herse, Herise, Halise, Aşür, Şuhut keşkeği, Babadağ keşkeği, Dedebağ keşkeği, Keşgâh, Haşıl, Masuta, Etli aşür, Etli aşüre, Hınıs, Çideme, Kel keşkek, Hıntiyye, Gendeme, Gendime pilavı, Merzifon keşkeği, Mısır keşkeği, İskilip, Keşkek çorbası, Keşkek pilavı, Karafırın keşkeği, Sütlü keşkek, Dartılı keşkek, Mısırlı keşkektir.

Pişirilme şekli bakımından keşkek odun ateşinde, fırında, tüplü ocakta ve tandırda pişirilmektedir. Ege Bölgesi'nde ateş üzerinde bakır kazanlar ile pişerken iç bölgelere doğru gidildiğinde fırınlarda pişirilme artmaktadır. İçerisinde bulunan malzemeye göre 
de yöreden yöreye değişen keşkek, Marmara Bölgesi ve Ege Bölgesi'nin bazı bölgelerinde tavuk eti ile hazırlanırken Ege ve Doğu Anadolu Bölgesi'nde küçükbaş hayvan eti kullanımı yaygındır. İç kesimlerde ise genellikle büyükbaş hayvan eti ile yapılan keşkek tüketilmektedir.

İncelenen keşkek türlerine göre rengi ve kıvamı genel olarak açık gri renginde ve macun kıvamındadır. Keşkeğin sunumunda genel olarak kırmızı yağ kullanılırken aynı zamanda bazı yörelerde yoğurt, yahni, eritilmiş tereyağı, salçalı yağ gibi ürünler kullanılarak sunum gerçekleştirmektedir. Doğu Anadolu Bölgesi'nde ortası açılarak eritilmiş tereyağı ile servis edilirken Ege Bölgesi'nde kırmızı yağ ile sunumu mevcuttur. Evlerde ve topluluklarda yapıldığı ve sunulduğu bilinen keşkek her yörede farklı amaçlar ile yapılmaktadır. Genel olarak dügüunlerde, bazı yörelerde ise nişan, özel gün, nevruz, doğum, Muharrem Ayı gibi ritüellerde sunumu yapılmaktadır.

Geçmişten bir miras olarak günümüze kadar gelen keşkek, günümüzde hak ettiği yerdedir ve sahip çıkılmaya devam edildiği sürece ile daha iyi yerlerde olacaktır. Bu çalışmada keşkek üzerine bölgesel farklılıklar literatür taraması ile ortaya konmaya çalışılmıştır. Bu kapsamda yapılacak diğer çalışmalarda görüşme ve/ veya anket yöntemlerini de kullanarak seçilen bir yöreye ait keşkek sunumu ile ilgili kalite algısı, gastro turistlerin bir yöredeki törensel keşkek sunumuyla ilgili memnuniyet düzeylerinin ölçülmesi vb. başlıklar doğrultusunda yapılacak çalışmalarla araştırmanın geliştirilmesi ve literatüre daha fazla katkı sağlanması hedeflenmektedir.

\section{Kaynakça}

Akın, G., Özkoçak, V., \& Gültekin, T. (2015). Geçmişten Günümüze Geleneksel Anadolu Mutfak Kültürünün Gelişimi. Ankara Üniversitesi Dil ve Tarih Coğrafya Fakültesi Antropoloji Dergisi,(30), 033-052.

Akkor, M. Ö. (2016). Komili Lezzet Seyahatnamesi. Anadolu Grubu.

Akkuş, Ç., \& Şimşek, A. (2019). Yöresel Yiyeceklerin Menülerde Yer Alma Düzeyleri: Kastamonu Örneği. International Vocational Schools Symposium (s. 45-54). Sinop: Sinop Üniversitesi.

Akkuş, G., Akkuş, Ç., \& Dönmez, Ö. Ç. (2019). Etkili Destinasyon Yöntemi Açısından Kastamonu İlçe Belediyeleri Bilgi Kaynaklarında Değinilen Gastronomik Unsurların Tespiti. Ganud International Conferance on Gastronomy (s. 427-439). Gaziantep: Nutrition and Dietetics.

Alptekin, Z. D. (2021). Kilis Manilerinde Yöresel Mutfak. Uluslararası Sosyal Araştırmalar Dergisi, 14(77), 163-175.

Arslantaş, F. (2020). Adana Yemek Kültürü. [Yayınlanmış Yüksek Lisans Tezi]. Pamukkale Üniversitesi.

Atasoy, Ö. A. (2019). Çorum: Keşkek. M. Y. Saçllık, \& S. Çevik içinde, Bir Yerin Tabaktaki Kimliği (s. 138-144). Detay Yainclik.

Aydın, T. (2000). Aydın Sofrası. Aydın.

Ayverdi, İ. (2005). Misalli Büyük Türkçe Sözlük (Cilt 2). Kubbealtı Neşriyatı.

Bozkurt, H., \& Özkoca, B. (2012). Manisa İli Kula İlçesi Çömlekçiliği. Batman Üniversitesi Yaşam Bilimleri Dergisi, 1(1), 659-671.

Çekiç, İ. (2015). Geçmişten Günümüze Törensel Bir Yemek: Keşkek. [Yayınlanmış Yüksek Lisans Tezi]. Gaziantep Üniversitesi.

Çelik, S. (2019). Afyonkarahisar: Kırk Hatimli Şifalı Aşure. M. Saçılık, \& S. Çevik içinde, Bir Yerin Tabaktaki Kimliği (s. 45-51). Detay Yayıncılık. 
Çildam, S. Y. (2021). Kültürel Coğrafya Denemesi Olarak Siirt Mutfak Kültürü. Atatürk Üniversitesi Sosyal Bilimler Enstitüsü Dergisi, 25(1), 305-325.

Çimrin, H. (2006). Bir Zamanlar Antalya, Yakın Zamana Yolculuk (Cilt 2). Antalya İl Kültür ve Turizm Halk Kültürü Arşivi.

Çınar, Z. (2019). Geçiş Dönemlerinde Mutfak Kültürü ve Yöresel Mutfak Uygulamaları: Ege Bölgesi'nde Nitel Araştırma. [Yayınlanmamış Yüksek Lisans Tezi]. Necmettin Erbakan Üniversitesi.

Demirel, H., \& Ayyıldız, S. (2017). Mutfak Kültürü ve Değişimi; Giresun İli Örneği. Journal of Tourism and Gastronomy Studies, 5(4), 280-298.

Demirel, H., \& Karakuş, H. (2019). Balıkesir Yeme İçme Kültürü ve Değişimi Üzerine Bir Alan Araştırması. Journal of Tourism and Gastronomy Studies, 7(2), 1383-1404.

Deniz, T., \& Yavaş, B. (2020). Karşılaştırmalı Bir Kültürel Coğrafya Araştırması: Bulak ve Yazıköy (Safranbolu) Kırsalında Keşkek Yapımı ve Kültürü. Journal of Humanities and Tourism Research, 10(3), 680-689.

Deniz, T., \& Yavaş, B. (2020). Karşılaştırmalı Bir Kültürel Coğrafya Araştırması: Bulak ve Yazıköy (Safranbolu) Kırsalında Keşkek Yapımı ve Kültürü. Journal of Humanities and Tourism Research, 10(3), 680-689.

Erol, M. (2004). Köy Hayırları'nın Yapısal ve İşlevsel Özellikleri Üzerine Bir İnceleme- Gökçealı Köy Örneği. Türk Bilimi Araştırmaları Dergisi, 16, 111-126.

Genç, N. A., \& Seçim, Y. (2019). Sinop Yöresel Mutağının Unutulmaya Yüz Tutmuş Tatlarının Değerlendirilmesi. Karadeniz Uluslararası Bilimsel Dergi, 44, 302-319.

Göde, H. A. (2017). Kültür Endüstrisine Örnek Olarak Isparta/ Yalvaç Ekmek Kültür ve Dünden Bugüne Mahalle Fırıncılığı. Folklor ve Edebiyat Dergisi, 23(91), 197-209.

Gök, Ç. (2019). Gümüşhane İli Kale Köyü ve Civar Köylerinin Ağız İncelemesi. [Yayımlanmamış Yüksek Lisans Tezi]. Uludağ Üniversitesi.

Gültekin, A. K. (2007). Tunceli'de Sünni Olmak:Ulusal ve Yerel Kimlik Öğelerinin Tunceli - Pertek'te Etnolojik Tetkiki. [Yayımlanmış Yüksek Lisans Tezi]. Ankara Üniversitesi.

Gümüşçü, O. (2018). Tarihi Çoğrafya ve Kültürel Miras. Erdem, 0(75), 99-120.

Ilıcak, N. G., \& Aydınalp, Ş. G. (2019). Amasya türkülerinde şehir imajına yönelik bir değerlendirme. Rumelide Deil ve Edebiyat Araştırmaları Dergisi, 15(6), 167-194.

Karakaş, A., \& Alkış, M. (2015). Çermik İlçesi Kırsal Turizm Potansiyelinin Belirlenmesi. Uluslararası Sosyal ve Ekonomik Bilimler Dergisi, 5(1), 01-08.

Keser, İ. (2005). Nusayrilik: Arap Alevileri. Karaman Kitapevi.

Mertol, H., \& Yaylacı, S. (2021). Gastronomi İşaretli Ürünler ve Gastronomik Lezletler: Tokat Örneği. Ă̆ri İbrahim Çeçen Üniversitesi Sosyal Bilimler Enstitüsü Dergisi, 7(1), 313-334.

Özdemir, M. Z. (2005). Türkiye'de Kültürel Mirasın Korunmasına Kısa Bir Bakış. Planlama, 20-25. Saatci, G. (2019). Analysis on the Use of Products with Geographical Indication as a Promotion Factor in the Case of Local Foods. Journal of Tourism and Gastronomy Studies, 7(1), 358374.

Sarı, E. (2011). Kurşunlu Mutfak Kültüründe Keşkek: Geçmişi, Bugünü ve Yarını. Milli Folklor, 23(90), 54-64.

Sarışık, M., \& Özbay, G. (2019). Ulusal Gastronomi ve Türk Mutfağı. Detay Yayınc1lık.

Şahin, H. (2018). Türk Mutfak Kültürü̈. Anadolu Üniversitesi.

Şentürk, M. (2019). Çankırı Yapraklı Çevrecik Köyü'nde Unutulmaya Yüz Tutmuş Dügün Gelenekleri. Uluslararası Halkbilimi Araştırmaları Dergisi, 2(2).

Sivrioğlu, S., \& Dale, D. (2019). Türk Mutfağında Bir Macera Anadolu. Nobel Yaşam.

Somut Olmayan Kültürel Mirasın Korunması Sözleşmesi: madde 2. Paris: UNESCO. (2003).

Teyin, G. (2020). Kültürel Bir Miras; Tören Keşkeği Geleneği. Gastroia: Journal of Gastronomy and Travel Research, 4(2), 313-321. 
Togay, D. (2016). Uşak İli Köyler Sözlüğü. silo.tips.

Topcuoğlu, S., \& Kiper, T. (2020). Tekirdağ İli Saray İlçesi Kırsal Yerleşimlerinin Kalkınmasına Yönelik Turizm Öncelikli Stratejilerin Belirlenmesi. Kent Kültürü ve Yönetimi Hakemli Elektronik Dergi, 13(3), 514-525.

Türk, H., \& Şahin, K. (2004). Antakya Geleneksel Yemek Kültürü. Mustafa Kemal Üniversitesi Sosyal Bilimler Enstitüsü Dergisi, 1(2).

Türker, A., \& Çelik, İ. (2012). Somut Olmayan Kültürel Miras Unsurlarının Turistik Ürün Olarak Geliştirmesine Yönelik Alteratif. Yeni Fikir(9), 89.

Uğurkan, E. (2019). Sakarya: Adapazarı Dartılı Keşkek. M. Y. Saçılık, \& S. Çevik içinde, Bir Yerin Tabaktaki Kimliği (s. 354-362). Detay Yayınc1lı.

Vurgun, S. Y. (2018). Geçmişten Günümüze Bilecik Bölgesi Manavlarının Sosyo-Kültürel Hayatlarının Analizi. Uluslararası Tarih Araştırmaları Dergisi, 3, 490-508.

Yörgüç, H. (2010). Amasya Mutfağı. Amasya Valiliği.

Yurday, Y. İ., \& Kıngır, S. (2019). İç Anadolu Bölgesi Mutfağı. M. Sarışık, \& G. Özbay içinde, Ulusal Gastronomi ve Türk Mutfağı (s. 373-450). Detay Yayıncılık.

Yücel, E., Özel, A. N., \& Şengül, İ. Y. (2013). Kemaliye (Erzincan) ilçesinde gıda olarak tüketilen bitkiler ve bölgeye has diğer yiyecekler. Biological Diversity and Conservation, 6(2), 3444 .

\section{Internet kaynakçaları}

Altınten,

D.

(25.05.2021).

Uşak

Keșkeği.

https://www.kulturportali.gov.tr/turkiye/usak/neyenir/keskek284259

Türk Patent Kurumu (2012). Adapazarı dartılı keşkek coğrafi işaret tescil belgesi. Ankara: https://www.turkpatent.gov.tr/TURKPATENT: Erişim Tarihi: 27.05.2021.

URL-1, 2021: https://mehmetkarbatan.wordpress.com/denizli-ili-gelenek-ve-gorenekleri/ , Erişim tarihi: 25.05 .2021 .

URL-2, 2021: https://groups.google.com/g/adzo/c/ietSdFFBFFQ?pli=1 Erişim tarihi: 27.05.2021.

URL-3, 2021: https://izmir.ktb.gov.tr/TR-77474/izmir-mutfagi.html/, Erişim tarihi: 25.05.2021.

URL-4, 2021: https://www.kulturportali.gov.tr/turkiye/izmir/neyenir/keskek335537 \#: :text= KE\%C5\%9EKEK\%20\%2D\%20\%C4\%B0zmir,et)\%20olu\%C5\%9Fan\%20geleneksel\%20 bir\%20yemektir, Erişim tarihi: 25.05.2021.

URL-5, 2021: https://www.naztic.org.tr/en/karacasu-keskegi-dedebag-keskegi/, Erişim tarihi: 27.05.2021.

URL-6, 2021: http://www.aytenusta.com.tr/Product/ProductDetail/826/kuzu-etli-keskek, Erişim tarihi: 25.05.2021.

URL-7，2021: https://www.kulturportali.gov.tr/turkiye/cankiri/neyenir/keskek142679, Erişim tarihi: 25.05.2021.

URL-8，2021: https://www.kulturportali.gov.tr/turkiye/kirsehir/neyenir/keskek235803, Erişim tarihi: 25.05 .2021$.

URL-9, 2021: https://www.sultanhani.gen.tr/herse-dovme-keskek-olsa-da-yesek/2949/, Erişim tarihi: 25.05.2021.

URL-10, 2021: https://www.hurriyet.com.tr/lezizz/hasil-nasil-yapilir-iki-farkli-hasil-tarifi41090057, Erişim tarihi: 27.05.2021.

URL-11， 2021: https://www.nefisyemektarifleri.com/masuta-keskek-elazig-yoresel-yemegi/, Erişim tarihi: 27.05.2021.

URL-12, 2021: $\quad$ https://hnsbaskoy.tr.gg/BA\%26\%23350\%3BK-Oe-Y-Y-Oe-RESELYEMEKLER\%26\%23304\%3B.htm, Erişim tarihi: 27.05.2021.

URL-13, 2021: https://lezzetler.com/cideme-keskek-malatya-tarif-32184, Erişim tarihi: 27.05.2021. URL-14, 2021: http://mus.gov.tr/mahalli-yemekler-mus, Erişim tarihi: 28.05.2021. 
URL-15, 2021: https://www.kulturportali.gov.tr/turkiye/van/neyenir/keskek248481, Erişim tarihi: 28.05.2021.

URL-16, 2021: http://www.turkish-cuisine.org/regional-cuisine-4/southeast-anatolian-region127/gaziantep-170.html?PagingIndex=1, Erişim tarihi: 28.05.2021.

URL-17， 2021: https://www.kulturportali.gov.tr/turkiye/diyarbakir/neyenir/keskek772404, Erişim tarihi: 28.05.2021.

URL-18, 2021: https://lezzetler.com/keskek-siirt-tarif-38943, Erişim tarihi: 28.05.2021.

URL-19， 2021: https://www.nefisyemektarifleri.com/siirt-usulu-keskek-hintiye-filfil/, Erişim tarihi: 28.05.2021.

URL-20, 2021: https://lezzetler.com/keskek-mardin-vt94466, Erişim tarihi: 28.05.2021.

URL-21, 2021: https://lezzetler.com/artvin-mutfagi-vt22773, Erişim tarihi:28.05.2021.

URL-22, 2021: https://www.turizmgunlugu.net/karadeniz-bolgesi-gastronomi Erişim tarihi:28.05.2021.

URL-23, 2021: https://www.nefisyemektarifleri.com/herse-bayburt, Erişim tarihi:28.05.2021.

URL-24，2021: https://www.gumushanevakfi.com/yoresel-yemekler-6b.html, Erişim tarihi: 28.05.2021.

URL-25, 2021: https://lezzetler.com/gendime-pilavi-gumushane-tarif-31046, Erişim tarihi:28.05.2021.

URL-26, 2021: https://www.gezenbilir.com/konu/trabzon-yemekleri.4140/ Erişim tarihi:28.05.2021.

URL-27, 2021: https://tokat.ktb.gov.tr/TR-143211/tokat-mutfagi.html, Erişim Tarihi: 29.05.2021.

URL-28， 2021: https://semihalindunyasi.blogspot.com/2015/11/tavuklu-keskek-samsunbafra.html, Erişim Tarihi: 29.05.2021.

URL-29, 2021: https://tr.wikipedia.org/wiki/\%C4\%B0skilip ke\%C5\%9Fke\%C4\%9Fi\#: : text=\%C4\%B0skilip\%20ke\%C5\%9Fke\%C4\%9Fi\%2C\%20\%C4\%B0skilip'e\%20\%C3\%B 6zg\%C3\%BC,f\%C4\%B1r\%C4\%B1nlarda\%20odun\%20ate\%C5\%9Fi\%20ile\%20pi\%C5 \%9Firilir, Erişim Tarihi: 30.05.2021.

URL-30, 2021: http://www.herrenk.com/sdetay.asp?id=1035\&did=1075, Erişim Tarihi: 30.05.2021.

URL-31, 2021: https://www.kulturportali.gov.tr/turkiye/karabuk/neyenir/sutlu-keskek-corbasi, Erişim Tarihi:29.05.2021.

URL-32, 2021: https://zonguldak.ktb.gov.tr/TR-92609/zonguldak-mutfak-kulturu.html, Erişim Tarihi: 30.05.2021.

URL-33, 2021: https://www.gastrofests.com/bolu-mutfagi/, Erişim Tarihi: 30.05.2021.

URL-34，2021: https://www.nefisyemektarifleri.com/keskek-trakya-usulu/, Erişim Tarihi: 30.05.2021.

URL-35, 2021: https://www.kulturportali.gov.tr/turkiye/tekirdag/neyenir/herise-keskek, Erişim Tarihi: 30.05.2021.

URL-36, 2021: https://www.kulturportali.gov.tr/turkiye/kocaeli/neyenir/tavuklu-keskek, Erişim Tarihi: 30.05.2021.

URL-37, 2021: https://www.kulturportali.gov.tr/turkiye/balikesir/neyenir/keskek913231, Erişim Tarihi: 30.05.2021. 